\title{
Islamic Education Curriculum in the Concept of the Koran
}

\author{
Mursal Aziz ${ }^{1}$ * Darliana Sormin ${ }^{2}$, Jailani Syahputra Siregar ${ }^{3}$, Dedi Sahputra \\ Napitupulu ${ }^{4}$, Rosmaimuna ${ }^{5}$
}

${ }^{1}$ STIT Al-Ittihadiyah North Labuhanbatu, North Sumatra, Indonesia
${ }^{2}$ Faculty of Islamic Studies, Muhammadiyah University of South Tapanuli, Indonesia
${ }^{3}$ Al-Washliyah University Labuhanbatu, Indonesia
${ }^{4}$ STIT Al-Ittihadiyah North Labuhanbatu, North Sumatra, Indonesia
${ }^{5}$ Faculty of Islamic Studies, Muhammadiyah University of South Tapanuli, Indonesia

*Corresponding author. E-mail: mursalaziz7@gmail.com

\begin{abstract}
The curriculum is the most important part of the educational process which serves as the direction of educational goals. Al-Qur'an as a holy book and a source of reference for life has actually given a signal that the importance of curriculum development, especially for Islamic educational institutions, is in accordance with the needs and demands of the times. By using literature analysis and analysis of the verses of the Koran, this research shows that the Koran wants a balance between the curriculum relating to general science and Islamic science. This research comes to the conclusion that the concept of the Koran does not recognize secularism and the dichotomy of the curriculum, but the ideal curriculum according to the Qur'an is an integrated and holistic curriculum.
\end{abstract}

Keywords: Curriculum, Islamic Education, Al-Qur'an

\section{INTRODUCTION}

The Qur'an is the holy book that every Muslim believes to be true without the slightest doubt. More than just a holy book, the Koran is for Muslims a source of reference to life. In facing the increasingly complex challenges of life, Muslims remain convinced that the Koran contains alternative answers as solutions to the problems of modern society. If this solution has not been found in the Qur'an, it is because of the limitations of human reason in digesting it. In the end, time will tell how the Qur'an is actually able to solve every problem in human life (Abdullah, 1990).

Because the Qur'an is universal, its contents are not only commands and prohibitions of God alone, but also related to all areas of life such as social, cultural, economic, political, and educational. In the contextks this research, the writer will tend to the educational aspects that are in the Al-Qur'an (Azia, 1967). Likewise, more specifically this research will lead to an Islamic education curriculum according to the concept of the Qur'an (AlSyaibani, 1984).
The curriculum is the most important substance in the world of education. The curriculum is the direction to be achieved in the world of education. Therefore, each educational institution has its own characteristics regarding the curriculum that is applied (Beauchamp, 1975). By using the approach of analysis of the Al-Qur'an literature study, this researchwill try to describe comprehensively the content of the Islamic education curriculum in the Koran and how it will develop in advancing Islamic education (hamalik, 1994).

This research is very important, because reorienting the curriculum in Islamic educational institutions is a necessity if you do not want to be left behind by public educational institutions or abandoned by Muslims themselves (Basri \& Saebani, 2010). At least a few people have done research on this subject, for exampleNorakyaire et al, said that redesigning the curriculum was to improve educational goal. Meanwhile, according to Islam and Sumadi that in order to respond to the times, what Islamic education institutions need to do is to design an integrated curriculum (Aziz, 2017). 
Meanwhile, according to Alhamuddin, in order to adapt to the times, Islamic educational institutions need to make changes to aspects of the curriculum. He prefers to offer a transdisciplinary curriculum development model that is oriented towards individuals and communities (Alhamduddin, 2017). Mesiono et al. Argue that the first step that Islamic education institutions must take in developing a curriculum is to formulate policies (Langgulung, 1998). Furthermore, Aziz added that there is a need for good governance or curriculum management to be able to achieve educational goals and answer the challenges of the times (Islami \& Sumadi, 2018).

\section{Definition of Curriculum}

In simple terms, the curriculum is a set of subjects that educators must convey to students. Even simpler, according to Beauchamp, that curriculum is an educational or teaching plan. Initially the curriculum was used as a track term for a runner (Norakyairee, 2017). However, recently it was adopted into one of the important terms in education and given the meaning as the educational time limit that a student must pass to get a diploma. Meanwhile, according to Tafsir, that the curriculum is more than just a plan and field of study that must be taken by students, it is all real experiences that occur in educational institutions (Napitupulu, 2020). To conclude some of the above opinions, it is interesting to quote Taba's opinion, that the curriculum is not just an implementation or plans, but the curriculum includes objectives, content, and educational methods that are more general in nature (Napitupulu, 2018).

In Islamic tradition, the curriculum is known as manhaj which means the light path through which humans carry out various life activities (Taba, 1962). According to Muhaimin, the clear way in question isthe path traversed by educators and students in maximizing knowledge, skills, attitudes and values. In the context of Islamic education it is often translated as a set of plans and media that serve as guidelines for educational institutions to achieve educational goals (Ramayulis, 1994).

\section{Al-Qur'an Signs Regarding the Curriculum Islamic education}

As explained above, that the purpose of the curriculum in Islamic education is as a means of achieving goals, as guidelines and programs that must be implemented, and as a standard in assessing success in Islamic education. Therefore, all Islamic education experts agree that the existence of the curriculum is very important and must always adapt to the times.
The content of the Islamic education curriculum in fact cannot be separated from the principle of Islam itself, namely the Al-Qur'an and Hadith. So the logical consequence of this statement is that the Islamic education curriculum must include the Qur'an and Hadith as the core content of the lesson. In addition, the values of the Qur'an and Hadith must always accompany every field of study in all Islamic educational institutions. This is in line with opinionAl-Syaibani stated that the characteristics of the Islamic education curriculum are 1), prioritizing religion and morals in the content, objectives and methods of Islamic education, 2) balance between world and hereafter affairs, 3) not forgetting the aspects of art, physical (sports), and knowledge of foreign languages, and 4) paying attention to the differences in interests and tendencies of students (Mesiono, 2019).

In addition, according to Basri and Saebani, it is also necessary to pay attention to several aspects related to the Islamic education curriculum, including 1) the main content of the curriculum is the guidance of students monotheism, 2) in line with human nature, 3 ) in line with the provisions of the Al-Qur'an an and Hadith, 4) directing the ability of the interests and talents of students, 5) developing the social morals of students, 6) a sustainable curriculum (Muhaimin, 2010).

Following up on the above principles, it can be put forward a kind of Islamic education curriculum formulation in the concept of the Koran. Starting from the explanation of the Koran in Surah Fussilat / 41: 53 it is explained that: "We will show them the signs of our (power) in all regions of the earth and in themselves, until it is clear to them thatAl-Qur'anit is true. Isn't it enough that your Lord is a witness to all things? ". Based on this verse it can be argued that the ideal Islamic education curriculum is as follows (Tafsir, 2011):

2.1. A curriculum that refers to monotheism. Namely the design of subjects that are oriented towards strengthening the faith of students. At the operational level, this knowledge is related to the knowledge of kalam, fiqh, morality / tasawuf, knowledge of the Qur'an and others.

2.2. A curriculum that refers to humanism. Namely the design of subjects related to aspects of humanity as a social being that has culture and civilization. At a more operational level, this science deals with history, politics, language, philosophy, psychology and others.

2.3. Curriculum that refers to nature. Namely the design of subjects related to the universe. If operationalized, this science is related to physics, chemistry, agriculture, fisheries, biology and so on. 
If we look at the signs of the above verses of the Qur'an, it can be assumed that Islam is actually a religion that does not only pay full attention to it the problem of the hereafter alone, but also provides a balanced portion of social and natural sciences. This is because indeed humans, regardless of their religion, were created by Allah SWT. Apart from being a servant who serves as a leader (caliph). And the most important requirement to be a leader is to have extensive knowledge.

Thus, it is very important to design an Islamic education curriculum that is able to balance the general sciences and religious sciences. Because among the most basic goals of human life is to get happiness in the world and in the hereafter (QS Al-Baqara / 2: 201). Once again, it needs to be emphasized that obtaining happiness in this world and in the hereafter is the main condition is mastery of comprehensive scientific disciplines. This is also in line with Allah's commandment.to master knowledge that is worldly, but does not immediately leave the afterlife knowledge (QS Al-Qashshas / 28: 77).

Signs regarding the importance of curriculum integration in Islamic education have actually started since the first verse was revealed (QS. Al-'Alaq / 96: 1$5)$. In this verse, it is explained so that people who hear or have reached the whahyu to him to read a lot as an effort to gain knowledge. However, it is not enough just to read. According toLastly, reading certainly involves good mental activity, recognition (cognition), memory (emory), observation (perception), pronunciation (verbalization), thinking (reasoning), and creativity (creativity). Furthermore, Langgulung explained that reading is a system of linkages between communication (communication system) and social system (social system)

If you want to dissect them one by one, it can be assumed that the Islamic education curriculum contained in surah Al-'Alaq / 96: 1-5 is as follows:

2.1. "Read in the name of your Lord who has created", is a sign of the ability to read which is associated with God as the Creator. And in this Islamic tradition it is known as naqliyah knowledge (perennial knowledge). It also offers at the same time that the main curriculum in Islamic education is related to monotheism.

2.2. "He created man from a clot of blood", is a sign that man is ordered to conduct research on himself. Obviously in plain view the desired educational curriculum in this case is related to biology. But furthermore this verse invites people to express things through the power of imagination and experience (acquired knowledge).
2.3. "Read, your most gracious God, who teaches people through the medium of a pen. He teaches humans what he doesn't know, "this verse suggests motivation so that humans are encouraged to explore the universe and then conduct research and write it down as evidence of civilization in writing to the next generation.

From the various concepts of the Islamic education curriculum contained in the Qur'an as described above, a sort of red thread can be drawn that the desired curriculum in Islamic education is an integrated and holistic curriculum. In Islamdoes not recognize secularism and the dichotomy of the curriculum between general knowledge and religion.

It is very interesting and in line with the above statement that a very famous scientist in the field of Islamic medicine, Ibn Sina, as quoted by Abdullah, argued that in the Islamic tradition the curriculum is divided into two parts, namely:

2.1. The nadhari curriculum (theoretical), namely science related to natural sciences, mathematics, and sciences related to divinity.

2.2. The amali (practical) curriculum, which is knowledge related to human behavior. The sciences related to this are moral, political, and philosophical sciences.

\section{Educational Curriculum Development Islam}

Whether we like it or not, we must admit that the condition of Islamic education today is very poor and is a little behind with general education institutions. Of course there are many factors that cause it. Maybe you need a separate research theme to describewhat are the causes of the decline and backwardness of these Islamic educational institutions. But what is certain is that making changes to a curriculum that is more modern and in accordance with the times is a necessity that must be done by managers of Islamic educational institutions.

If you want to make a simple comment on the direction of the development of the Islamic education curriculum, the writer chooses the word "adjusting to the times". The essence of real curriculum development is being able to adapt to the increasingly sophisticated and modern times. So all education is required to reorient curriculum that is more relevant to the demands of the times. This has also been indicated in the Qur'an that every human being must be able to see opportunitieswhat a very promising future. Contemplating and compiling strategic plans to deal with changes that are so fast (QS Al-Hasyr / 59: 18).

As an example, that the world is currently incessantly conducting discussions and corrections to extreme 
weather changes that can threaten human existence on earth. According to many experts and research results, the main cause of climate change is the massive environmental destruction carried out by humans. Responding to this, educational institutions, especially Islamic education institutions, should pay serious attention to environmental issues, one of the ways is by integrating the Islamic education curriculum and the environment.

The curriculum is a set of subjects and educational programs provided by an educational provider which contains lesson plans that will be given to participants in one education level. The arrangement of these subject instruments is adjusted to the circumstances and abilities of each level of education in the provision of this education as well as the needs of the job field. The length of time in a curriculum is usually adjusted to the aims and objectives of the education system being implemented.

The Islamic education curriculum is intended to be able to direct education towards the direction and goals intended in learning activities as a whole. It is an activity to produce a curriculum at the level of an educational unit or the process of linking one component to another to produce a curriculum. Curriculum development can also be interpreted as the activity of compiling, implementing, assessing and refining the curriculum. In its development, the curriculum involves various parties, especially those who directly or indirectly have an interest in the existence of education designed, namely from education experts, educators, students, education officials, practitioners and role models or community members who other.

Basically, curriculum development is the level of accuracy (validity) and reliability of the principles used. This has something to do with the sources of the principles of curriculum development itself. There are data, facts, concepts, and principles whose level of trust is unquestionable because they have been proven empirically through repeated research. There is also data that has been proven empirically, but it is still limited in certain cases so that it cannot be generalized. There is even data that has not been proven in a study, but has been proven in life and according to common sense considerations is seen as logical, good, and useful. In relation to curriculum development, educators are the key persons who best understand the needs of the curriculum in accordance with students and the demands of the times. Therefore, it is very natural that the role of the teacher is expected to participate actively in curriculum development.

Islamic education institutions are the spearhead of curriculum implementation, which is manifested in learning to achieve goals in accordance with national education standards. In order for the learning process to be carried out effectively and efficiently, and to achieve the expected results, learning system management activities are needed, as a whole process to carry out learning activities effectively and efficiently.

\section{CONCLUSION}

The curriculum is the most important element in education, therefore reorienting the curriculum in accordance with the times is a necessity so that Islamic educational institutions are not left behind or left behind. As a very holy referenceAl-Qur'an gives a signal that the ideal curriculum for Islamic education institutions, namely the curriculum is integrated and holistic, and the concept of the Koran does not recognize secularism and the dichotomy of the curriculum between general knowledge and religion.

\section{REFERENCES}

[1] Abdullah, A. S. (1990). Teori-Teori Pendidikan Berdasarkan Al-Qur'an. Jakarta: Rineka Cipta.

[2] Al-Syaibani, O. M. T. (1984). Falsafah Pendidikan Islam. Jakarta: Bulan Bintang.

[3] Azia, R. S. (1967). Curriculum Principles and Foundation. New York: Harper and Row Publisher.

[4] Aziz, M. (2017). Manajemen Kurikulum dalam Pengembangan Budaya Belajar di Madrasah Aliyah Mu'allimin Univa Medan. Ittihad, 1(2), 198-208.

[5] Basri, H., \& Saebani, B. A. (2010). Ilmu Pendidikan Islam. Bandung: Pustaka Setia.

[6] Beauchamp, G. A. (1975). Curriculum Theory. Illonis: The KAGG Press.

[7] Hamalik, O. (1994). Kurikulum dan Pembelajaran. Bandung: Bumi Aksara.

[8] Islami, N., \& Sumadi. (2018). Pengembangan Kurikulum Terpadu Pendidikan Agama Islam Sistem Full Day School. Jurnal Penelitian Pendidikan Islam, 6(1), 133-146. Alhamuddin. (2017). Transdiciplinary: Model Pengembangan Kurikulum Berorientasi Kebutuhan Individu dan Masyarakat. Jurnal Pendidikan Islam Indonesia, 2(1), 55-64.

[9] Langgulung, H. (1988). Asas-Asas Pendidikan Islam. Jakarta: Pustaka Al-Husna.

[10] Mesiono, A. M., \& Syafaruddin. (2019). Implementasi Kebijakan Pengembangan Kurikulum Madrasah Aliyah Qismul'Aly Medan. Ta'dib, 22(2), 57-66.

[11] Muhaimin. (2010). Pengembangan Kurikulum 
Pendidikan Agama Islam, di Sekolah, Madrasah, dan Perguruan Tinggi. Jakarta: PT. Raja Grafindo Persada.

[12] Napitupulu, D. S. (2018). Madrasah Ramah Lingkungan. Medan: CV. Widya Puspita.

[13] Napitupulu, D. S. (2020). Etika Profesi Guru Pendidikan Agama Islam. Sukabumi: Haura Utama.

[14] Norakyairee, H., Raus, H. M., \& Nabil, N. A. (2017). Model dan Kurikulum Pendidikan AlQuran Holistik Bagi OKU. J-QSS: Journal of Quran Sunnah Education and Special Needs, 1(1), $1-15$.

[15] Ramayulis. (1994). Ilmu Pendidikan Islam. Jakarta: Kalam Mulia.

[16] Taba, H. (1962). Curriculum Development: Theory and Practicestle. New York: Harcourt, Brace and World.

[17] Tafsir, A. (2011). Ilmu Pendidikan Islami. Bandung: Remaja Rosdakarya. 